Contested Ground 



\title{
Contested Ground
}

HOW TO UNDERSTAND THE LIMITS OF PRESIDENTIAL POWER

\author{
Daniel A. Farber
}

曰 UNIVERSITY OF CALIFORNIA PRESS 
University of California Press

Oakland, California

(C) 2021 by Daniel Farber

Library of Congress Cataloging-in-Publication Data

Names: Farber, Daniel A., 1950- author.

Title: Contested ground : how to understand the limits of presidential power / Daniel Farber.

Description: Oakland, California : University of California Press, [2021] | Includes bibliographical references and index.

Identifiers: LC C N 2021001867 (print) | LC C N 2021001868 (ebook) | IS B N 9780520343948 (cloth) | Is B N 9780520975279 (epub)

Subjects: LC S H: Executive power-United States. | PresidentsUnited States. | Separation of powers-United States. | United States. Supreme Court-Decision making.

Classification: LC C KF 5O53.F37 2021 (print) | LCC KF5O53 (ebook) | D D C 342.73/o62-dc23

LC record available at https://lccn.loc.gov/2021001867

LC ebook record available at https://lccn.loc.gov/2021001868

Manufactured in the United States of America

$\begin{array}{llllllllll}30 & 29 & 28 & 27 & 26 & 25 & 24 & 23 & 22 & 21\end{array}$

$\begin{array}{llllllllll}10 & 9 & 8 & 7 & 6 & 5 & 4 & 3 & 2 & 1\end{array}$ 
To my grandchildren, Joe Jr., Helene, and Emma 
